\title{
Pozice institucionálních investorů v ekonomice se nelepší
}

\section{Vážení čtenáři,}

současná situace na finančních trzích potvrzuje platnost axiomu o nemožnosti dosáhnout všech tř́ vrcholů magického trojúhelníku, kterými jsou stabilita a klientská bezpečnost, zamezení morálnímu hazardu a negativnímu výběru a efektivnost finančního byznysu. Snaha o předejití opakování nedávné destruktivní krizové amplitudy je vedena cestou masivní regulace, která má za cíl preferovat první dva vrcholy onoho trojúhelníku a má tudíž svůj adekvátní dopad na efektivnost finančních trhů. Současný obrázek není zatím zrovna nejpovzbudivější. Prokazuje to snižující se efektivnost významných institucionálních investorů $\mathrm{v}$ ekonomice - bank a pojišt'oven, které by kolektováním dočasně volných prostředků od drobných klientů měly tyto zdroje vracet do ekonomiky a přispívat tak k ekonomickému růstu. Podívejme se, zda je tomu tak opravdu.

V nejvýznamnějším segmentu českého finančního trhu - bankovním sektoru - je na jedné straně evidentní přebytek likvidity, který spíše než $\mathrm{k}$ potřebě deficitních subjektů $\mathrm{v}$ ekonomice a tedy $\mathrm{k}$ financování investic přifukuje vytvářející se bubliny, na straně druhé je implementován regulatorní projekt Basel III, znamenající zpřísňování regulace likvidity bank, což se mi jeví jako nekonzistentní, ne-li př́imo schizofrenní. Na říjnové výroční konferenci České bankovní asociace zazněl v diskusi asi vcelku výstižný výrok: „reguluje se, až se práší“. K zvyšování efektivnosti bankovnictví a funkci prorůstového institucionálního investora to jistě nepřispívá.

V otázce efektivnosti je ovšem na tom hůře odvětví pojišt’ovnictví, navíc se aktuálně vytvořila velmi kuriózní situace, která ve svém konečném výsledku na Českou republiku rozhodně nebude vrhat nejlepší světlo. V zemích Evropské unie bude od 1. ledna 2016 povinně implementován regulatorní projekt Solvency II, který bude znamenat mimořádně výrazný zásah do ekonomickolegislativního rámce celého odvětví. Projekt je postaven na matematickém modelování, tedy na mimo jiné již překonaném prrístupu „risk based approach“, tedy iluzi, že lze exaktně měřit riziko. Přesto, že ke koncepci projektu byly vznášeny relevantní metodologické výhrady, byl po dlouhých létech kontraverzních diskuzí a odkladů nakonec schválen a od roku 2016 začne na území Evropské unie povinně platit.

To byl také hlavní důvod, proč byl u nás vypracován nový návrh na úpravu stěžejní normy pro ekonomicko-legislativní rámec odvětví, Zákona o pojišstovnictví. Hlavním cílem návrhu bylo sladit naši legislativu s konečnou 
podobou realizace regulatorního projektu. V příslovečný listopadový pátek 13 . byla parlamentem novela ve třetím čtení zamítnuta, přestože předchozí koaliční dohoda jej předurčovala k hladkému průběhu Poslaneckou sněmovnou a druhé čtení tento předpoklad podpořilo.

Zamítnutí návrhu zákona o pojišt’ovnictví nepochybně souvisí s vytvořením nerovnováhy ve vztahu pojistitelů a zprostředkovatelů pojištění, je to tristní obraz kř́žžení obchodních zájmů a silových vlivů. Nejmarkantnějším důsledkem vyostřeného konfliktu byla po delší dobu existence silně nerovnovážné situace v životním pojištění: pojištovny v posledních létech vyplácely miliardy korun na získatelských provizích, pojištěnost životním pojištěním ale nerostla. Nejkontroverznější součástí novely byla tudíž regulace získatelských provizí a rozložení jejich výplat na pět let (ze statistik je zřejmé, že zhruba polovina nové produkce životního pojištění do pěti let zanikne). Problémem, který situaci vyvolal, je tzv. přetáčení životních pojistek, kdy je hlavním důvodem přepracování pojistky získání nové provize za sjednání - zprostředkovatel v takovém př́ípadě nedbá prvořadě zájmu klienta, ale hlavně svého vlastního. Jde evidentně o selhání tržního mechanismu, který nedokáže vrátit tuto tržní interakci do rovnováhy a v takovém případě není jiné cesty než regulace. Variant k zamezení bezdůvodného přetáčení životních pojistek je asi více, jde o to najít konsenzus nad tou tržně nejkonformnější.

Důsledek střetu zájmů je tristní. Právníci v České národní bance jakožto dohlížiteli nad pojistným trhem si nyní lámou hlavu nad situací v lednu 2016, kdy unijní směrnice začne platit bez transpozice do českého práva, takže po určitou dobu bude české pojišt’ovnictví podléhat ustanovení dvou právních norem. Přitom praktická implementace modifikované regulace bude nepochybně přinášet pojišt'ovnám problémy, které vždy vznikají při zavádění něčeho nového, u nás přibude komplikace $\mathrm{s}$ absencí harmonizace směrnice s naším právem, navíc Česká republika bude za nezvládnutí procesu hladkého přijetí směrnice sankcionována.

Je ovšem v těchto souvislostech třeba zmínit ještě jeden aspekt, týkající se našeho dohánění úrovně zemí Evropské unie v pojištěnosti právě životním pojištěním, které kromě vytváření dočasně volných finančních prostředků pro uplatnění na finančních trzích představuje významnou alternativu financování postaktivního věku. Současná obecně slabá výkonost finančních trhů zejména v instrumentech s nízkou rizikovostí prakticky zlikvidovala produkt kapitálového životního pojištění, kde o umístění dočasně volných peněžních prostředků klientů rozhodoval portfolio manažer pojišt'ovny: pojistitelé mají problém zajistit dostatečné finanční zdroje z konzervativních investic pro klientům garantovaný výnos, ten je $\mathrm{v}$ současných poměrech pro klienty nezajímavý. Č́stečným řešením je produkt investičního životního pojištění, kde si pole působnosti pro investiční uplatnění svých dočasně volných prostředků v rezervě životního pojišsění vybírá sám klient, čímž ovšem na sebe bere riziko své volby. 
PŘEDMLUVA - Daňhel, J.: Pozice institucionálních investorů v ekonomice se nelepší.

Každopádně funkce životní pojišt'ovny jako institucionálního investora je v současných podmínkách oslabena.

Ekonomický svět je př́liš složitý a $\mathrm{v}$ mnoha ohledech i virtuální a iracionální, problémy krystalicky ukazují na potřebu zásadních změn podmínek pro institucionální investory v ekonomice. Komplikované státní zásahy a rigidní regulace nevedou k obratu. Tudíž se nabízí otázka možné alternativy: snižování vlivu regulačních zásahů státních a nadnárodních institucí na finančním trhy a na institucionální investory a návrat k vyšší tržní spontaneitě.

prof. Ing. Jaroslav Daňhel, CSc.

Katedra bankovnictví a pojištovnictví Fakulta financi a účetnictví

Vysoká škola ekonomická v Praze 